\title{
The Relationship between Type and Frequency of Online Food Ordering with Obesity in Students of Medan Area University
}

\author{
Laila Apriani Hasanah Harahap ${ }^{1}$, Evawany Aritonang $^{2}$, Zulhaida Lubis ${ }^{2}$ \\ ${ }^{1}$ Student of Master in Public Health Faculty, Universitas Sumatera Utara, Indonesia \\ ${ }^{2}$ Lecturer of Public Health Faculty, Universitas Sumatera Utara, Indonesia \\ Email: apryanihasanah@yahoo.com
}

\begin{abstract}
:
Online food ordering is a food delivery service through applications that are obtained quickly and safely. This is related to obesity. This type of research uses a descriptive type of study, with a cross sectional study design. This research was conducted at Medan, Medan University with 83 samples taken using purposive sampling method. The data used are primary data obtained based on measurements of student weight and height, recall and food frequency are analyzed by chi-square test. The results of the study showed that there was a correlation between the frequency of online food ordering with obesity $(p<0.001)$ and there was no correlation between the types of food and obesity $(p=0.099)$ in the students of Medan Area University. To deal with the problem of obesity, it is easy to get access to online food ordering.

Keywords:

type; frequency of online food ordering; obesity; student
\end{abstract}

\section{Introduction}

Online food ordering is a food delivery service through applications that can be quickly and safely. With the emergence of various online food ordering applications that support and make it easier for everyone to order food without leaving the house. This is related to the lack of physical activity and life which are accompanied by stress, especially in big cities, starting to show the impact of increasing the problem of over nutrition or obesity (Khasanah, 2012).

The diet, especially in big cities, shifts from traditional eating patterns to western patterns (especially in the form of fast food). Shifting diets whose composition contains high calories, fat, carbohydrates, and sodium, but low in fiber such as fast food and soft drinks cause an imbalance of nutritional intake and is a risk factor for the emergence of obesity and decreases in physical activity that are primarily seen in large cities (Almatsier, 2011).

Based on Bowen's research (2015), it shows that there is a relationship between energy intake, fat intake, protein intake and obesity. In the study it was found that samples that were obese were those who consumed high energy, protein and fat.

There is currently evidence that the prevalence of being overweight and obesity is increasing very sharply at the whole world, which reaches a dangerous level. Obesity is not only found in the adult population, but also in children and teenagers (Adriani, 2012).

One risk factor for obesity is a low level of physical activity. Current technological advances are the cause of the low physical activity carried out (Sundari, 2015). Changes in diet and physical activity result in more people experiencing more nutritional problems. Excessive eating patterns and lack of physical activity can cause bad body metabolism so that it will cause 
more nutrition. More nutrition is considered important because it can cause degenerative diseases that currently occur in Indonesia.

According to data from the World Health Organization (WHO) in 2015, the rate of obesity in the world in 2014 was $11.9 \%$ and more than 1.9 billion adults over 19 years were overweight, and obese people were more than 600 million. Overweight and obesity are the biggest risks of global death. About 3.4 million teenagers die each year because of these two things.

Based on the requirements of the World Health Organization, overweight and obesity are risk factors for number five causes of death. At least 2.8 million people die per year due to overweight and obesity. Overweight and obesity have a high mortality rate in the world compared to underweight. WHO has stated that obesity has become an epidemic in both developed and developing countries. In Europe, the prevalence of obesity ranges from $6-20 \%$ in men and 6 $30 \%$ in women.

Based on a preliminary survey by conducting interviews with students who ordered 30 food online and measuring body weight and height, there were 12 people with normal nutritional status, 8 people with more nutritional status and 5 obese people.

\section{Research Methods}

The type of research used was a descriptive type of study, with a cross sectional study design. The sample used in this study were 83 students of the 2015 and class of 2016 Faculty of Economics at the Medan Area University who ordered food online in the last month. Samples were taken by purposive sampling method.

Data on obesity is obtained by measuring the body weight and height of the respondent. Measurement of weight and height is carried out using digital scales and microtoise. After that, the Body Mass Index (BMI) is determined. Online food ordering data is obtained through the food frequency form that has been determined by the researcher to see the frequency and type of food ordered through online.

Data analysis was carried out by univariate and bivariate analysis. Univariate analysis was conducted to see the distribution of gender data frequency, type and frequency of ordering online food and obesity. While the bivariate analysis was performed using the chisquare test, to see the relationship between the type and frequency of ordering online food with obesity in Medan Area University students.

\section{Discussion}

\subsection{Results}

\section{a. Characteristics of Respondents}

Characteristics of respondents surveyed in this study were gender, type and frequency of online food ordering and obesity. This type of food is categorized as complete if it consists of staple foods, side dishes, vegetables and fruits. Incomplete categorization if one or more of the food groups is not available. Order frequency is categorized frequently if $>3 x$ in one week and rarely if $<3 \mathrm{x}$ in one week. In Table 1 shows that the majority of students are women $(58.0 \%)$, types of food ordered online are incomplete $(62.7 \%)$, frequency of ordering food online is rare $(79.5 \%)$ and not obesity $(74.7 \%)$ 
Table 1. Distribution of Respondent Characteristics

\begin{tabular}{|l|c|c|}
\hline Characteristics & $\begin{array}{c}\text { Amount } \\
\text { (n) }\end{array}$ & $\begin{array}{c}\text { Percentage } \\
\text { (\%) }\end{array}$ \\
\hline Gender & & \\
\hline Female & 48 & 58.0 \\
\hline Male & 35 & 42.0 \\
\hline Food Type & & 37.3 \\
\hline Complete & 31 & 62.7 \\
\hline Incomplete & 52 & \\
\hline Order Frequency & & 20.5 \\
\hline Often & 17 & 79.5 \\
\hline Rarely & 66 & \\
\hline Nutritional status & & 25.3 \\
\hline Obesity & 21 & 74.7 \\
\hline Not obese & 62 &
\end{tabular}

\section{b. The Relationship between Types and Frequency in Ordering Online Foods with Obesity}

The results of the analysis showed that there was no relationship between the types of food ordered in ordering online food with obesity in Medan Area University students $(\mathrm{p}=$ 0.099). Of the 31 students who ordered a complete diet, 35, 5\% were obese and 64, 5\% were not obese. Then from 52 students who ordered food types were incomplete, $19.2 \%$ were obese and $80.8 \%$ were not obese.

The results of the analysis of the relationship between the frequency of online ordering and obesity showed that there was a relationship between the frequency of online ordering with obesity in University Medan Area students $(p<0.001)$. Of the 17 students who often ordered food online, $82.4 \%$ were obese and $17.6 \%$ were not obese. Of the 66 students who rarely ordered food online, $10.6 \%$ were obese and $89.4 \%$ were not obese. The results of bivariate analysis can be seen in Table 2 .

Table 2. Relationship to the Types and Frequency of Ordering Online Foods with Obesity

\begin{tabular}{|l|c|c|c|c|c|}
\hline \multirow{2}{*}{ Variable } & \multicolumn{4}{|c|}{ Nutritional Status } & \multirow{2}{*}{ P Value } \\
\cline { 2 - 5 } & \multicolumn{2}{|c|}{ Obesity } & \multicolumn{2}{c|}{ No obesity } & \multirow{2}{*}{} \\
\cline { 2 - 5 } & $\mathbf{N}$ & $\mathbf{0}$ & $\mathbf{N}$ & $\mathbf{0}$ & \\
\hline Types of \\
$\begin{array}{c}\text { Food Online } \\
\text { Complete }\end{array}$ & 11 & 35,5 & 20 & 64,5 & \multirow{2}{*}{0.099} \\
Incomplete & 10 & 19,2 & 42 & 80.8 & \\
\hline $\begin{array}{l}\text { Ordering } \\
\text { Frequency of } \\
\text { Online Foods } \\
\text { Often } \\
\text { Rarely }\end{array}$ & 7 & 14.6 & 59 & 89.4 & \multirow{2}{*}{$<0.001$} \\
\hline
\end{tabular}

\subsection{Discussion}

\section{a. The Relationship between Types of Food Pre- Ordered in Ordering Food Online with} Obesity

The type of food most ordered in ordering food online is a type of food that is not complete. The results showed that there was no relationship between the types of food ordered in online ordering with obesity. Arlinda's (2015) research results, one factor that can influence 
obesity is the availability of cheap, fast but unhealthy food, one of which is fast food.

Results research conducted Prima (2018) also mentions that the incidence of obesity can be affected by food consumption factors such as junk food and physical activity. This was reinforced by a study conducted by Trushna Shah et al in 2014 with 138 students, 58.4\% of students agreed that they liked fast food and $34 \%$ of them consumed fast food not because there was no home food but because of the lifestyle or the lifestyle of the teenagers.

The results of research conducted by Dewi and Trias (2013) shows that the source of carbohydrates consumed is rice $59.8 \%$ with the highest frequency in men 3 times per day amounting to $39.1 \%$ and women 2 times per day at $21.8 \%$ other than that Research results also show that employees consume meatballs is $29.8 \%$ with the highest frequency in men 2 times / week of $13.8 \%$ and for women 1 time / week by $7.2 \%$. According to data obtained from 87 samples, there were $56.3 \%$ have poor nutritional status, namely central obesity.

Based on the results of research conducted and the results of previous studies, it can be seen that this type of food plays a role in increasing the risk of obesity in people who consume it, especially fast food types that are widely ordered through online applications. This is because fast food offers affordable prices, serving fast and meeting current tastes. The low ordering of complete food types consisting of staple foods, side dishes, vegetables and fruit in this study was due to insufficient student food budget and the desire to consume different foods from daily meals. In addition, food products in online applications also do not all provide a complete type of food.

\section{b. The Relationship between Ordering Frequency of Online Foods with Obesity.}

The frequency of ordering food online is relatively rare, which is $<3$ times a week. However, students who often order food online are $>3$ times a week, the majority are obese. The results showed that there was a correlation between the frequencies of ordering online food with obesity in Medan Area University students.

Obesity is more common in adults, the higher the age of a person, the higher the risk for obesity. Students enter into the early adult age group. The results of Victor's (2013) study showed the prevalence of obesity in students of the Faculty of Medicine and Health Sciences at Tamale University, Ghana was 9.8\%. In this study obesity occurs in students who have less physical activity and consume alcoholic beverages and consume coffee.

WHO states that a lifestyle with a lack of activity is one of the top ten causes of death and disability in the world. In most countries around the world between $60 \%-85 \%$ of adults do not have enough physical activity to maintain their health (Balitbangkes, 2008). Unhealthy food consumption, consuming too much food containing fat and cholesterol and lack of fiber intake can trigger degenerative diseases.

The results of the identification were carried out by Riskesdas, that the risk factors that cause degenerative diseases in North Sumatra stated that $51.9 \%$ of the people of North Sumatra lack physical activity or exercise. The percentage of overweight and obesity that occurred in North Sumatra was $31.1 \%$. In the field cities the percentage of overweight and adult obesity is $38.1 \%$ (Riskesdas, 2013).

A study conducted by Mustelin (2009) showed that that there was a significant relationship between physical activity and obesity. The results of bivariate analysis showed that 
respondents who did not routinely exercise had a risk of obesity by 1.35 times compared to respondents who routinely exercised. In addition, it turns out that teenagers who do not routinely exercise actually tend to have higher energy intake than those who exercise regularly. Food and physical activity can affect the emergence of better nutrition together or individually.

According to Virgianto and Purwaningsih, (2006) lack of physical activity causes a lot of energy stored as fat, so that people who do less activity tend to be fat. One of the disadvantages of easy access to information, such as the online food ordering application is to reduce the physical activity of the users of the application.

Application users are made easy to not do activities outside the house but the food they want can be delivered to the house. This greatly facilitates Medan Area University students, where not all students have vehicles to buy the food they want, can avoid hot weather, can avoid vehicle smoke, and can avoid the traffic jams in Medan City.

This is exacerbated by the type of food consumed which is mostly incomplete types of food, such as fast food. After not doing physical activity to buy food out of the house, students consume fast food, then they will remain at home without doing other physical activities. So there is accumulation of fat which causes obesity. So it can be concluded that, the more often students order food online, the greater the risk of being obese.

Excessive energy intake and not balanced with balanced energy expenditure (with less physical activity) will cause weight gain. Changes in lifestyle lead to changes in people's diet which refers to a diet high in calories, fat and cholesterol, and not balanced with physical activity can cause more nutritional problems (Hidayanti, 2010).

\section{Conclusion}

The results of this study can be concluded that more female students do online food ordering than male students. The type of food ordered is classified as an incomplete type of food which means that it does not fulfill one or more types of staple foods, side dishes, vegetables and fruit. Online food ordering is also not often done, that's $<3$ times a week. There is no relationship between the types of food ordered on ordering food online with obesity. There is a relationship between the ordering of online food orders with obesity at the University of Medan Area students.

\section{References}

Almatsier, S. (2011). Basic Principles of Nutrition Science. Jakarta: Gramedia.

Linda, S. (2015). Fast Food Consumption Relationship with Obesity in Adolescents at 10 Muhammadiyah Middle School Yogyakarta. Thesis, Aisyiyah High School of Health Sciences Yogyakarta.

Bowen, L. et al. (2015). Association between diet, physical activity and body fat distribution, a cross sectional study in an Indian population. BMC Public health 15: 281.

Hasanah, N. (2012). Beware of Various Degenerative Diseases Due to Diet. First Print. Yogyakarta: Publisher Laksana.

Mustelin, L. et al. (2009). Physical activity and effects on BMI and waist circumference: a study in young adult twins. International Journal of Obes. 33: 29-36.

Prima, A., Hafni, A., Mars, N. (2018). The relationship of Junk Food Consumption and Physical Activity to Adolescent Obesity in your B Aceh. Volume 3 No. February 1. 
RISKESDAS. (2013). Basic Health Research. Jakarta: Health Research and Development Agency, Ministry of Health, Republic of Indonesia.

Sundari, E., Masdar, H., Rosdiana, D. (2015). Rates of Central Obesity in the City of Pekanbaru. JOM FK, Volume 2 No.2, October.

Victor, Mogre, Aleyira, S. and Nyaba R. (2013). Factors associated with overweight and obesity in students. Attending the University for Development Studies in Tamale, Ghana: a cross sectional study. S Afr J Clin Nutr: 27 (2): 69 - 74.

Virgianto, G. and Purwaningsih, E. (2006). Fast Food Consumption as a Risk Factor for Obesity in Teens. http// www. m3undip.org/ accessed on May 102018. 